\title{
Haematological and Genotoxic effects of cadmium chloride on Mesopotamichthys sharpeyi
}

\author{
Noor M. Salman \\ AbdAlmotalib J. Al-Rudainy \\ Department of Pathology, College of Veterinary Medicine, University Baghdad, \\ Baghdad, Iraq. \\ Received 2/3/2015 \\ Accepted 26/4 /2016 \\ (1) $(9)$ \\ under a Creative Commons Attribution-NonCommercial-
} NoDerivatives 4.0 International Licens

\begin{abstract}
:
The present study investigated Haematological changes in Mesopotamichthys sharpeyi, as well as determination genotoxic effects of cadmium chloride on bunni fish by using 120 fingerlings, fish were distributed randomly into four treatments in addition to control group. Fish in first group treated (T1) with cadmium 0.093mg/L with changing water and added cadmium continuously, fish in the second group treated (T2) with cadmium $0.093 \mathrm{mg} / \mathrm{L}$ with changing water without adding cadmium, third treatment (T3) with cadmium $0.046 \mathrm{mg} / \mathrm{L}$ with changing water and adding cadmium continuously, and fourth treatment (T4) with cadmium $0.046 \mathrm{mg} / \mathrm{L}$ with changing water without adding cadmium. Results of blood picture in T1 and T3 showed a significant reduction in red blood cells count, hemoglobin concentration, packed cell volume values, while the number of white blood cells showed a significant increase in its values. Results showed presence of improvement of clinical and microscopical signs and blood picture in T2 and T4, were changed water aquarium continuously and added cadmium only once compared withT1 and T3.

Results of the present study concluded that changing water aquarium in the treatments without adding cadmium led to improvement of health status of fish which increased with the passage of time results of blood picture were almost the same of the control group. It could be concluded from the current study that the adding of cadmium to water aquarium containing bunni fish led to decrease in red blood cells count, hemoglobin and packed cell volume values and increase in micronuclei number.
\end{abstract}

Key words: Cadmium Chloride, Haematological, Mesopotamichthys sharpeyi.

\section{Introduction:}

Fish are an important source of food for human. It has been advised that fish should be consumed two or three times weekly, due to the need of omega 3 polyunsaturated fatty acids, which found abundantly in fish oil[1]. Water pollution with heavy metals is growing problem, Heavy metals cannot be degraded, they are deposited, assimilated or incorporated in water, sediment and aquatic animals [2], that causing pollution in water bodies. In an aquatic environment, metal toxicity can be influenced by various abiotic environmental factors such as oxygen, hardness [3], pH, alkalinity and 
temperature [4]. Cadmium can accumulate in some organs of fish which cause lethal and a variety of sub lethal effects [5]. Among these toxic substances, heavy metals constitute one of the main dangerous groups, because they are toxic, persistent and not easily biodegraded [6 and 7]. The aims of the present study include: Detecting of Cadmium effect on some blood parameters (WBC, RBC, PCV, Hb) and Studying genotoxic effect of cadmium by using micronuclei assay.

\section{Materials and Methods:}

The study was conducted at the College of Veterinary Medicine, University of Baghdad, Ichthyology Laboratory. A total of 120 fingerlings of Bunni fish $M$. sharpeyi ranging between $8-10 \mathrm{~cm}$ in total length and $10-$ $15 \mathrm{gm}$ in body weight, with no visible signs of disease or morbidity, were obtained from (Al-Swerra Hatchery) and acclimated to laboratory condition for 15 days before beginning of the experiments. Fish were briefly bathed in Nacl for 5min to remove all external parasite if present. Blood collection was done via cardiac puncture technique, blood was withdrawn directly from heart at the end of the experiment which extended for three months by a sterile disposable syringe and blood was transferred to EDTA tube for haematological tests. Modified Dices Fluid was used to dilute blood to count RBCs and WBCs by haemocytometer chamber. [8]. PCV was measured by using microhematocrit according to the method mentioned by [9]. The determination of hemoglobin by colorimetric method which is converted into cyanomethemoglobin under the influence of potassium ferricyanide and potassium cyanide [10].

Micronucleus tests in RBC were detected in peripheral blood smears of blood obtained by cardiac puncture or blood smear from gills [11]. The slides were air-dried for $24 \mathrm{~h}$, fixed in methanol for $10 \mathrm{~min}$, followed by $10 \%$ Giemsa (v/v) staining. Micronuclei were detected in 2000 erythrocytes/fish by microscopical examination at $1000 \mathrm{X}$ oil-immersion lens [12].

\section{Results and Discussion:}

Results of WBCs count $\left(\mathrm{Cell} / \mu \mathrm{Lx} 10^{3}\right)$ in blood of Mesopotamichthys sharpeyi which exposed to repeated different concentrations of cadmium chloride for three months are shown in Table (1).

Results of WBCs count gave significant increase $(\mathrm{p} \leq 0.05)$ in $\mathrm{T} 1$, and $\mathrm{T} 3$, which reached to $(28.20 \pm 0.20) \times 10^{3} / \mathrm{mm}^{3}$ in T1 and $(24.50 \pm 0.13) \times 10^{3} / \mathrm{mm}^{3}$ in T3 at the end of the experiment compared with control group which ranged $21.85 \pm 0.02) \times 10^{3} / \mathrm{mm}^{3}$. No significant variation between T2 $(21.90 \pm 0.02) \times 10^{3}$ $/ \mathrm{mm}, \mathrm{T} 4(21.90 \pm 0.04) \times 10^{3} / \mathrm{mm}^{3}$ at the end of the experiment compared to control group. The statistical analysis showed significant increase $(p \leq 0.05)$ in WBCs of T1and T3 compared to control group, as well as T1and T2 after 2 weeks, 1 month, 2 and 3 month respectively.

On the other hand results showed a significant increasing $(\mathrm{p} \leq 0.05)$ in WBCs value within $\mathrm{T} 2$ in the beginning of the experiment compared to the end which showed no significant increase compared to control group.

Statistical analysis results showed no significant variations in WBCs value of T4 during experimental period, which noticed the same results compared to control group.

Results of RBCs count (Cells/ $\mu \mathrm{L}$ x $10^{6}$ ) in blood of M.sharpeyi which exposed to repeated different concentrations of cadmium chloride for three months are shown in Table( 1 ).

These results of RBCs count give significant decrease $(\mathrm{p} \leq 0.05)$ in $\mathrm{T} 1$, and $\mathrm{T} 3$, which reached to $(1.50 \pm 0.04) \times 10^{6}$ $/ \mathrm{mm}^{3}$ in $\mathrm{T} 1$ and $(1.50 \pm 0.07) \times 10^{6} / \mathrm{mm}^{3}$ in 
T3 at the end of the experiment compared with control group ranged $(2.32 \pm 0.01) \times 10^{6} / \mathrm{mm}^{3}$. While $\mathrm{T} 2$ and T4 don't give significant variation between T2 $(2.27 \pm 0.02) \times 10^{6} / \mathrm{mm}^{3}$ and T4 $(2.33 \pm 0.01) \times 10^{6} / \mathrm{mm}^{3}$ at the end of the experiment compared to control group.

Results of PCV (\%) of M.sharpeyi which exposed to a repeated different concentrations of cadmium chloride are shown in Table (1).

Results of PCV count give significant decreasing $(\mathrm{p} \leq 0.05)$ in $\mathrm{T} 1$, and $\mathrm{T} 3$, which reached to $(22.70 \pm 1.80)$
$\%$ in $\mathrm{T} 1$ and $(27.00 \pm 0.70) \%$ in $\mathrm{T} 3$ at the end of the experiment compared to control group which ranged $(38.00 \pm 1.20) \%$. And no significant variation between T2 $(36.00 \pm 1.20) \%$ and T4 $(34.00 \pm 1.20) \%$ at the end of the experiment compared to control group.

The results of hemoglobin $(\mathrm{Hb})(\mathrm{gm}$ /dl) are shown in Table (1). There was a significant decrease in values at $(\mathrm{p} \leq 0.05)$ in all treated groups along the period of the experiment in comparison with the control group value in blood of M. sharpeyi which exposed to treated concentrations of cadmium chloride.

Table 1: Hematological tests $( \pm$ S.D.) of M.sharpeyi which exposed to different concentrations of Cadmium chloride during experiment period.

\begin{tabular}{|c|c|c|c|c|}
\hline $\begin{array}{l}\text { Heam.tests } \\
\text { Treatmets }\end{array}$ & $\begin{array}{c}\text { Mean WBC } \\
\times 10^{3} / \mathrm{mm}^{3}\end{array}$ & $\begin{array}{c}\text { Mean RBC } \\
\times 10^{6} / \mathrm{mm}^{3}\end{array}$ & Mean PCV\% & $\begin{array}{c}\text { Mean Hb } \\
\mathrm{gm} / \mathrm{dl}\end{array}$ \\
\hline Control & $\begin{array}{c}21.85 \pm 0.02 \\
F\end{array}$ & $\begin{array}{c}2.32 \pm 0.01 \\
\mathrm{~A}\end{array}$ & $\begin{array}{c}38.00 \pm 1.20 \\
\mathrm{~A}\end{array}$ & $\begin{array}{c}15.42 \pm 0.70 \\
\mathrm{~A} \\
\end{array}$ \\
\hline \multicolumn{5}{|c|}{2 week } \\
\hline T1 (0.093) & $\begin{array}{c}22.60 \pm 0.07 \\
\mathrm{E} \mathrm{a}\end{array}$ & $\begin{array}{c}2.12 \pm 0.02 \\
\mathrm{~B} \mathrm{~b}\end{array}$ & $\begin{array}{c}34.00 \pm 2.31 \\
\mathrm{~B} \mathrm{~b}\end{array}$ & $\begin{array}{c}12.90 \pm 1.19 \\
\mathrm{AB} \mathrm{b}\end{array}$ \\
\hline T2 (0.093) & $\begin{array}{c}22.32 \pm 0.16 \\
\text { E a }\end{array}$ & $\begin{array}{c}2.10 \pm 0.05 \\
\mathrm{~B} \mathrm{~b}\end{array}$ & $\begin{array}{c}34.00 \pm 1.20 \\
\mathrm{~B} \mathrm{~b}\end{array}$ & $\begin{array}{c}12.02 \pm 1.28 \\
\mathrm{AB} \mathrm{b}\end{array}$ \\
\hline T3 (0.046) & $\begin{array}{c}22.25 \pm 0.11 \\
\mathrm{E} \mathrm{a} \\
\end{array}$ & $\begin{array}{c}2.12 \pm 0.07 \\
\mathrm{~B} \mathrm{~b}\end{array}$ & $\begin{array}{c}37.00 \pm 0.70 \\
\mathrm{AB} \text { ab }\end{array}$ & $\begin{array}{c}15.70 \pm 0.68 \\
\mathrm{~A} \mathrm{a}\end{array}$ \\
\hline $\mathrm{T} 4(0.046)$ & $\begin{array}{c}21.95 \pm 0.01 \\
\mathrm{~F} \mathrm{~b}\end{array}$ & $\begin{array}{c}2.20 \pm 0.01 \\
\mathrm{AB} \mathrm{ab}\end{array}$ & $\begin{array}{c}34.00 \pm 1.20 \\
\mathrm{~B} \mathrm{~b}\end{array}$ & $\begin{array}{c}12.80 \pm 0.89 \\
\mathrm{AB} \mathrm{b}\end{array}$ \\
\hline \multicolumn{5}{|c|}{1 month } \\
\hline T1 (0.093) & $\begin{array}{c}23.38 \pm 0.24 \\
\text { D a }\end{array}$ & $\begin{array}{c}1.86 \pm 0.02 \\
\mathrm{C} \mathrm{b}\end{array}$ & $\begin{array}{c}32.70 \pm 0.70 \\
\text { BC b }\end{array}$ & $\begin{array}{c}12.10 \pm 0.03 \\
\mathrm{AB} \mathrm{b}\end{array}$ \\
\hline T2 (0.093) & $\begin{array}{c}22.23 \pm 0.05 \\
\mathrm{E} \mathrm{b}\end{array}$ & $\begin{array}{c}2.16 \pm 0.02 \\
\mathrm{~B} \mathrm{a}\end{array}$ & $\begin{array}{c}36.00 \pm 1.20 \\
\mathrm{AB} \mathrm{a}\end{array}$ & $\begin{array}{c}13.70 \pm 0.70 \\
\mathrm{AB} \mathrm{a}\end{array}$ \\
\hline T3 (0.046) & $\begin{array}{c}22.35 \pm 0.22 \\
\text { E b }\end{array}$ & $\begin{array}{c}1.92 \pm 0.01 \\
\mathrm{C} \mathrm{b}\end{array}$ & $\begin{array}{c}34.00 \pm 1.20 \\
\mathrm{~B} \mathrm{ab}\end{array}$ & $\begin{array}{c}11.90 \pm 0.80 \\
\mathrm{AB} \text { ab }\end{array}$ \\
\hline $\mathrm{T} 4(0.046)$ & $\begin{array}{c}22.03 \pm 0.06 \\
\mathrm{E} \mathrm{b}\end{array}$ & $\begin{array}{c}2.24 \pm 0.01 \\
\mathrm{AB} \mathrm{a}\end{array}$ & $\begin{array}{c}36.70 \pm 2.31 \\
\mathrm{AB} \mathrm{a}\end{array}$ & $\begin{array}{c}13.90 \pm 1.10 \\
\mathrm{AB} \mathrm{a}\end{array}$ \\
\hline \multicolumn{5}{|c|}{2 month } \\
\hline T1 (0.093) & $\begin{array}{c}25.90 \pm 0.20 \\
\text { B a }\end{array}$ & $\begin{array}{c}1.62 \pm 0.02 \\
\mathrm{C} \mathrm{b}\end{array}$ & $\begin{array}{c}27.30 \pm 1.80 \\
\mathrm{D} \mathrm{b}\end{array}$ & $\begin{array}{c}8.40 \pm 1.30 \\
\mathrm{~B} \mathrm{~b}\end{array}$ \\
\hline T2 (0.093) & $\begin{array}{c}21.93 \pm 0.02 \\
\text { F c }\end{array}$ & $\begin{array}{c}2.19 \pm 0.03 \\
\mathrm{AB} \text { a }\end{array}$ & $\begin{array}{c}36.00 \pm 1.20 \\
\mathrm{AB} \text { a }\end{array}$ & $\begin{array}{c}13.60 \pm 1.30 \\
\mathrm{AB} \mathrm{a}\end{array}$ \\
\hline T3 (0.046) & $\begin{array}{c}23.50 \pm 0.25 \\
\mathrm{D} \mathrm{b}\end{array}$ & $\begin{array}{c}1.70 \pm 0.10 \\
\mathrm{Cb}\end{array}$ & $\begin{array}{c}30.70 \pm 0.70 \\
\text { DC b }\end{array}$ & $\begin{array}{c}12.10 \pm 0.03 \\
\mathrm{AB} \text { ab }\end{array}$ \\
\hline T4 (0.046) & $\begin{array}{c}21.90 \pm 0.02 \\
\text { F c }\end{array}$ & $\begin{array}{c}2.30 \pm 0.02 \\
\mathrm{~A} \mathrm{a}\end{array}$ & $\begin{array}{c}35.00 \pm 0.70 \\
\mathrm{AB} \text { a }\end{array}$ & $\begin{array}{c}11.90 \pm 0.60 \\
\mathrm{AB} \text { ab }\end{array}$ \\
\hline \multicolumn{5}{|c|}{3 month } \\
\hline T1 (0.093) & $\begin{array}{c}28.20 \pm 0.20 \\
\mathrm{~A} \mathrm{a}\end{array}$ & $\begin{array}{c}1.50 \pm 0.04 \\
\mathrm{Cb}\end{array}$ & $\begin{array}{c}22.70 \pm 1.80 \\
\mathrm{~Eb}\end{array}$ & $\begin{array}{c}5.12 \pm 1.20 \\
\text { B b }\end{array}$ \\
\hline $\mathrm{T} 2(0.093)$ & $\begin{array}{c}21.90 \pm 0.02 \\
\text { F c }\end{array}$ & $\begin{array}{c}2.27 \pm 0.02 \\
\mathrm{AB} \text { a }\end{array}$ & $\begin{array}{c}36.00 \pm 1.20 \\
\mathrm{AB} \text { a }\end{array}$ & $\begin{array}{c}13.60 \pm 1.30 \\
\mathrm{AB} \text { a }\end{array}$ \\
\hline $\mathrm{T} 3(0.046)$ & $\begin{array}{c}24.50 \pm 0.13 \\
\mathrm{C} \mathrm{b}\end{array}$ & $\begin{array}{c}1.50 \pm 0.07 \\
\mathrm{Cb}\end{array}$ & $\begin{array}{c}27.00 \pm 0.70 \\
\mathrm{D} \mathrm{b}\end{array}$ & $\begin{array}{c}7.60 \pm 0.60 \\
\mathrm{~B} \mathrm{~b}\end{array}$ \\
\hline $\mathrm{T} 4(0.046)$ & $\begin{array}{c}21.90 \pm 0.04 \\
\text { F c }\end{array}$ & $\begin{array}{c}2.33 \pm 0.01 \\
\mathrm{~A} \mathrm{a}\end{array}$ & $\begin{array}{c}34.00 \pm 1.20 \\
\mathrm{BC} \mathrm{a}\end{array}$ & $\begin{array}{c}13.50 \pm 0.60 \\
\mathrm{AB} \text { a }\end{array}$ \\
\hline
\end{tabular}

* Different vertically capital letters represent significant variations at $\mathrm{p} \leq 0.05$ in different periods

* Different vertically small letters represent significant variations at $\mathrm{p} \leq 0.05$ in same period. 
Cadmium compounds present in various organs of animals or cause huge modification in plant and fish biomass production [13]. After entering into the organs of freshwater fishes through the gills, cadmium binds to albumins and erythrocytes in the blood and then is transferred into tissues and organs where it is bound to proteins of low molecular mass producing metallothioneins by the induction of metallothionein mRNA synthesis [14].

The increase in WBCs count can be correlated with an increase in antibody production which helps in survival and recovery of the fish exposed to lindane and malathion [15]. In the present study, the significant increase in WBCs count indicates hypersensitivity of leucocytes to cadmium chloride and these changes may be due to immunological reactions to produce antibodies to cope up with stress induced by cadmium chloride. [16] reported that WBCs increase could be result of proliferation, of pluripotential hematopoietic cells that, in turn, may be a consequence of a depletion circulating differentiated. The increase in WBCs count in the present study indicates the stress condition of the fish caused by cadmium chloride toxicity which might produce gill damage and other organs.

The decrease in RBCs count during the chronic treatment might be resulted from severe anemic state or haemolysing power of heavy metals (cadmium chloride) particularly on the red cell membrane. this agreed with [17] the reduction in erythrocytes count might be due to the destruction of mature erythrocytes and the inhibition of erythrocytes production.

Changes in the erythrocyte profile suggest a compensation of oxygen deficit in the body due to gill damage and the nature of the changes shows a release of erythrocytes from the blood depots [18]. Inhibition of erythropoiesis and an increase in the rate of erythrocyte destruction in hematopoietic organs are the cause of decrease in RBCs count [15].

According to [19] the reduction in haemoglobin content in fish exposed to toxicant could also be due to the inhibitory effect of toxic substance on the enzyme system responsible for synthesis of $\mathrm{Hb}$.

The reduction in erythrocyte count, PCV and haemoglobin of Cyprinus carpio can be attributed to the following factors, haemodilution of blood due to the damage of fish organs [20 and21] and the haematological parameters PCV, RBCs and $\mathrm{Hb}$, whose changes can be interpreted as a compensatory response that improves the $\mathrm{O}_{2}$ carrying capacity to maintain the gas transfer, also indicates a change in the water blood barrier for gas exchange in gill lamellae [22].

The results of micronuclei test (Table 2) showed bunni fish sensitivity to $\mathrm{cdcl}_{2}$ increases in micronuclei rates in erythrocytes in acute and chronic exposure whith high record of a significant increasing at $(\mathrm{p} \leq 0.05)$ for period (90) days from exposure in $\mathrm{T} 1$ (0.093 mg/L) (Fig. 1) which was 23.02 compared with micronuclei no. in the beginning of the experiment which was 0.80 , caused by adding of $\mathrm{cdcl}_{2}$ continuously during experiment period after change of water aquarium. But the control group showed no significant varations between mean of the micronuclei in the end of the experiment 0.60 and its mean in the beginning of the experiment 0.56 .

T2 (0.093 mg/L) (Fig. 2) the significant increase at $(p \leq 0.05)$ for period (90) days from exposure less effect than T1 micronuclei no. was 8.43 compared with micronuclei no. in the beginning of the experiment which was 0.72 due to adding $\mathrm{cdcl}_{2}$ only one time in the beginning of the experiment and 
water changing continuously without adding $\mathrm{cdcl}_{2}$.

T3 (0.046 mg/L) (Fig. 3) the significant increase at $(\mathrm{p} \leq 0.05)$ for period (90) days of exposure. recorded 14.05 compared with micronuclei no. in the beginning of the experiment which was 0.49 that's due to adding $\mathrm{cdcl}_{2}$ continuously with changing water aquarium.

T4 (0.046 mg/L) (Fig. 4) did not show any significant variation at for period (90) days from exposure 1.00 compared with micronuclei number in the beginning of the experiment which was 0.84 that caused by adding less concentration of $\mathrm{cdcl}_{2}$ only in the beginning of the experiment periods and continuous water changing.

Table 2: The micronuclei test of M.sharpeyi which exposed to different concentrations of cadmium chloride during experiment period.

\begin{tabular}{|c|c|c|}
\hline Treatment $(\mathrm{mg} / \mathrm{L})$ of Cd. & $\begin{array}{c}\text { Initial } \\
\text { experiment }\end{array}$ & $\begin{array}{c}\text { Final } \\
\text { experiment }\end{array}$ \\
\hline Control & $\begin{array}{c}0.56 \pm 0.04 \\
\mathbf{A}\end{array}$ & $\begin{array}{c}0.60 \pm 0.08 \\
\mathbf{A ~ d ~}\end{array}$ \\
\hline $\mathrm{T} 1(0.093)$ & $\begin{array}{c}0.80 \pm 0.23 \\
\text { B }\end{array}$ & $\begin{array}{c}23.02 \pm 0.49 \\
\mathrm{~A} \mathrm{a}\end{array}$ \\
\hline $\mathrm{T} 2(0.093)$ & $\begin{array}{c}0.72 \pm 0.11 \\
\text { B }\end{array}$ & $\begin{array}{c}8.43 \pm 0.40 \\
\text { A c }\end{array}$ \\
\hline $\mathrm{T} 3(0,046)$ & $\begin{array}{c}0.49 \pm 0.13 \\
\text { B }\end{array}$ & $\begin{array}{c}14.05 \pm 0.23 \\
\mathrm{~A} \mathrm{~b}\end{array}$ \\
\hline $\mathrm{T} 4(0.046)$ & $\begin{array}{c}0.84 \pm 0.28 \\
\mathbf{A}\end{array}$ & $\begin{array}{c}1.00 \pm 0.36 \\
\mathrm{Ad}\end{array}$ \\
\hline $\begin{array}{l}\text { Different horizon } \\
\text { represent significant } \\
\text { Different vertically } \\
\text { significant variations }\end{array}$ & $\begin{array}{l}\text { ly cap } \\
\text { riations } \\
\text { mall lett } \\
\mathrm{t} \mathrm{p} \leq 0.05\end{array}$ & $\begin{array}{l}\text { letters } \\
\leq 0.05 . \\
\text { represent }\end{array}$ \\
\hline
\end{tabular}

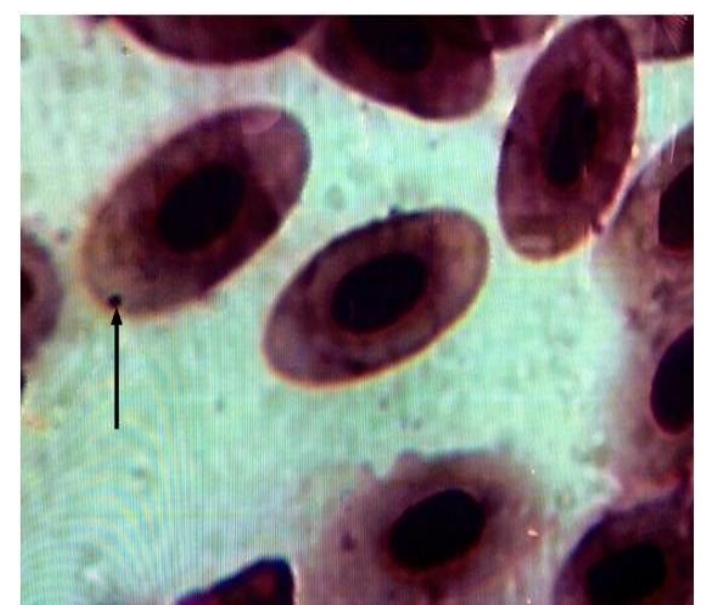

Fig. 1: Micronuclei in erythrocytes in T1 (Giemsa x1000).

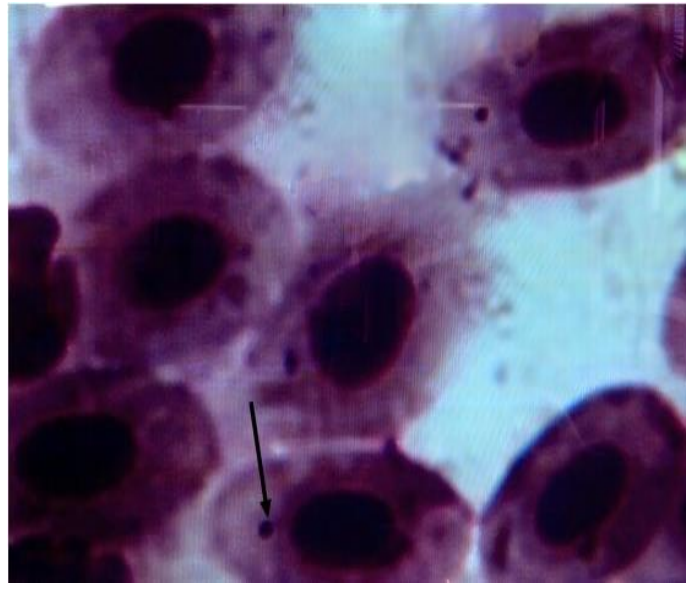

Fig. 2: Micronuclei in erythrocytes in T2 (Giemsa x1000).

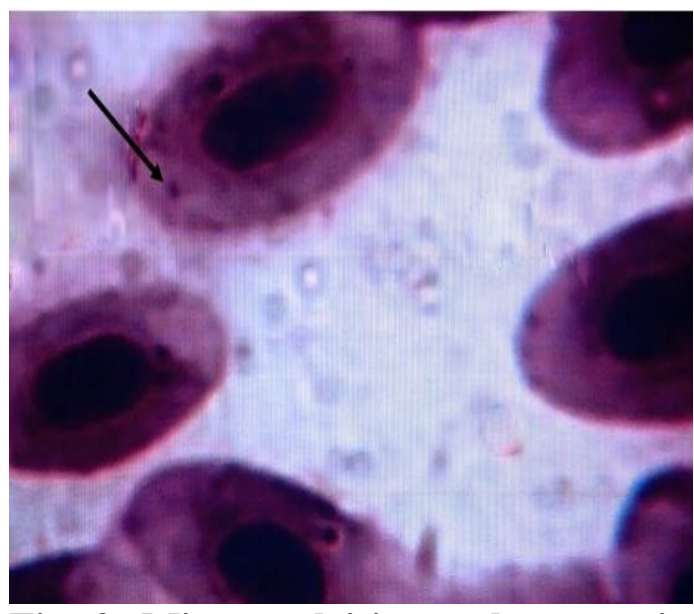

Fig. 3: Micronuclei in erythrocytes in T3 (Giemsa x1000).

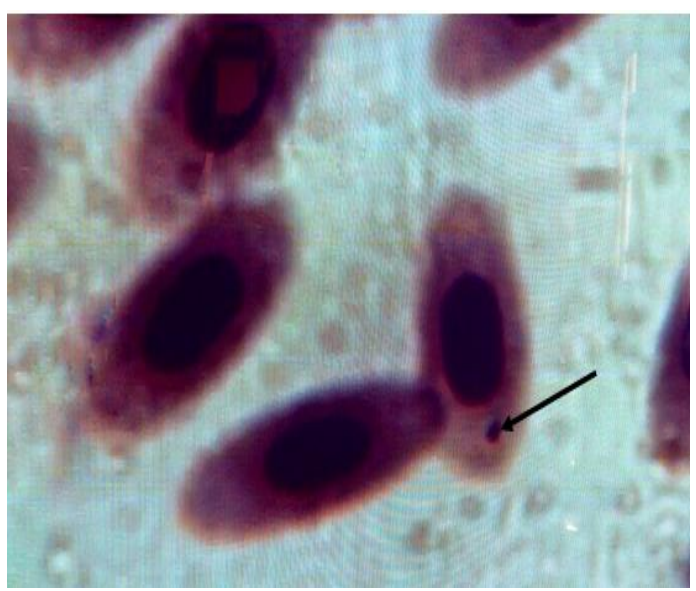

Fig. 4: Micronuclei in erythrocytes in T4 (Giemsa x1000)

[23 and 24] suggested that the mechanism of cadmium genotoxicity is mainly conditioned by single strand breaks in DNA through the direct 
cadmium-DNA interactions as well as by the action of excision nuclei and/or DNA-glycosylase during DNA repair.

Presence of micronuclei belong to effect of cadmium chloride in erythroblast in liver, kidney and spleen, these organs which produce erythrocyte, The cell which contains one micronuclei or more, referred to cell division process. The erythrocyte don't divid in peripheral blood system so that failed in migration towards the poles. Most probablythe source of micronuclei in erythrocytes haemopoitic producing cells. The effects of cadmium on genetic material of erythrocyte lead to micronuclei formation in some areas and different chromosomes [25].

It could be concluded from the current study that the adding of cadmium to water aquarium containing M.sharpeyi led to decrease in red blood cells count, hemoglobin and packed cell volume values and increase in micronuclei number .

\section{References:}

[1] Hu, F. B.; Cho, E.; Rexrode, K. M.; Albert, C. M. and Manson, J. E. 2003. Fish and long-chain omega-3 fatty acid intake and risk of coronary heart disease and total mortality in diabetic women. Circulation, 107:1852-1857.

[2] Linnik, P. M. and Zubenko, I. B. 2000. Role of bottom sediments in the secondary pollution of aquatic environments by heavy-metal compounds. Lakes and Reservoirs: Research and Management, 5:11-21.

[3] Ghillebaert, F.; Chaillou, C.; Deschamps, F. and Roubaud, P. 1995. Toxic effects of three $\mathrm{pH}$ levels, of two reference molecules on common carp embryo. Ecotoxicol. and Environ. Safe., 32: 19-28.

[4] Adhikari, S.; Ghosh, L. and Ayyappan, S. 2006. Combined effect of water $\mathrm{pH}$ and alkalinity on the accumulation of lead, cadmium and chromium to Labeo rohita (Hamilton). International J. Environ. Sci. and Tech., 3(3): 289-296.

[5] Ozmen, M.; Güngördü, A.; Kucukbay, F. Z. and Güler, R. E. 2006. Monitoring the effects of water pollution on Cyprinus carpio in Karakaya Dam Lake, Turkey. Ecotoxicol. (London, England), 15: 157- 169.

[6] Sabadell, J. E. and Axtmann, R. C. 1975. Heavy metal contamination from geothermal sources. Environ. Health Perspectives, 12: 1-7.

[7] Ellis, A. J. 1997. Geothermal fluid chemistry and human health. Geothermics, 6: 175-182.

[8] Dacie, J. V. and Lewis, S. M. 1984. Practical haematology, Churchill livingston ed., selecto printing Co.ltd., New York, 445P.

[9] Archer, R. K. 1985. Haematological techniques for use on animals. Blakwell Sci. publ., Oxford, pp:3744.

[10] Coles, E.H. 1986. Veterinary clinical pathology. 4th edition. Saunders, W. B. Company, Philadelphia, 122:110-115.

[11] Al-Sabti, K. 1986. Comparative micronucleated erythrocyte cell induction in three cyprinids by five carcinogenic-mutagenic chemicals, Cytobios., 47 :147 P.

[12] Fagr, A.; El-shehawi, A. M. and Seehy, M. A. 2008. Micronucleus test in fish genome: A sensitive monitor for aquatic pollution,African J.Biotechnol., 7:606-612.

[13] Barman, S. C. and Lal, M. M. 1994. Accumulation of heavy metal ( $\mathrm{Zn}$, $\mathrm{Cu}, \mathrm{Cd}$ and $\mathrm{Pb}$ ) in soil and cultivated vegetables and weeds growing industrially polluted fields. J. Environ. Biol., 15: 107-115.

[14] George, S. G.; Todd, K. and Wright, J. 1996. Regulation of metallothionein in teleosts induction of MTm-RNA and protein by cadmium in hepatic and extrahepatic 
tissues of a marine flat fish, turbot (Scophthalmus maximus). Comp. Biochem. Physiol. C., 113: 109-115

[15] Joshi, P. and Deep, H. 2002. Effect of lindane and malathion exposure to certain blood parameters in a freshwater teleost fish Clarias batrachus. Poll. Res., 21: 55-57.

[16] Fink, N. E. and Salibian, A. 2005. Toxicological studies in adult amphibians: effects of lead. Appl. Herpetol., 2(3): 311-333.

[17] James, R. and Sampath, K. 1999. Effect of the ion-exchanging agent, Zeolite, on reduction of cadmium toxicity: an experimental study on growth and elemental uptake in Heteropneustes fossilis (Bloch). J. Aquacul. Trop., 14: 65-74.

[18] Drastichova, J.; Svobodova, Z.; Luskova, V. and Machova, J. 2004. Effect of cadmium on hematological indices off common carp, Cyprinus carpio L. Bull. Environ. Contam.Toxicol., 72: 725-732.

[19] Pamila, D.; Subbaiyan, P. A. and Ramaswamy, M. 1991. Toxic effect of chromium and cobalt on Sartherodon massambicus (peters). Ind. J. Environ. Hlth., 33:218-224.

[20] Morgan, D. P.; Stockdale, E. M.; Roberts, R. J. and Walter, H. W.
1980. Anemia associated with exposure to lindane. Arch. Environ. Health, 35: 307-310.

[21] Sweilum, M. A. 2006. Effect of sublethal toxicity of some pesticides on growth parameters, haematological properties and total production of Nile tilapia (Oreochromis niloticusL.) and water quality of ponds. Aquac. Res., 37: 1079-1089.

[22] Jee, J. H.; Masroor, F. and Kang, J. C. 2005. Responses of cypermethrininduced stress in haematological parameters of Korean rockfish, Sebastes schlegeli (Hilgendorf). Aquac. Res., 36: 898-905.

[23] Privezentsev, K. V.; Sirota, N. P. and Gaziev, A. J. 1996. The genotoxic effects of cadmium studied in vivo. Tsitol. Genet., 30: 45-51.

[24] Lutzen, A.; Liberti, S. E. and Rasmussen, L. J. 2004. Cadmium inhibits human DNA mismatch repair in vivo. Biochem. Bioph. Res. Co., 321: 21-25.

[25] Chatterjee, K. K.; Talukder, G. and Sharma, A. 1982. Effects of synthetic pyrethroids on mammalian chromosomes: I. Sumicidin. Mutat Res., 105:101-106. 


\title{
التأثيرات الدموية والسمية الوراثية لكلوريد الكادميوم على \\ Mesopotamichthys sharpeyi
}

\author{
عبدالمطلب جاسم الرديني
}

نور محمد سلمان

فرع الامر اض، كلية الطب البيطري ،جامعة بغداد، ،بذاد ، العراق

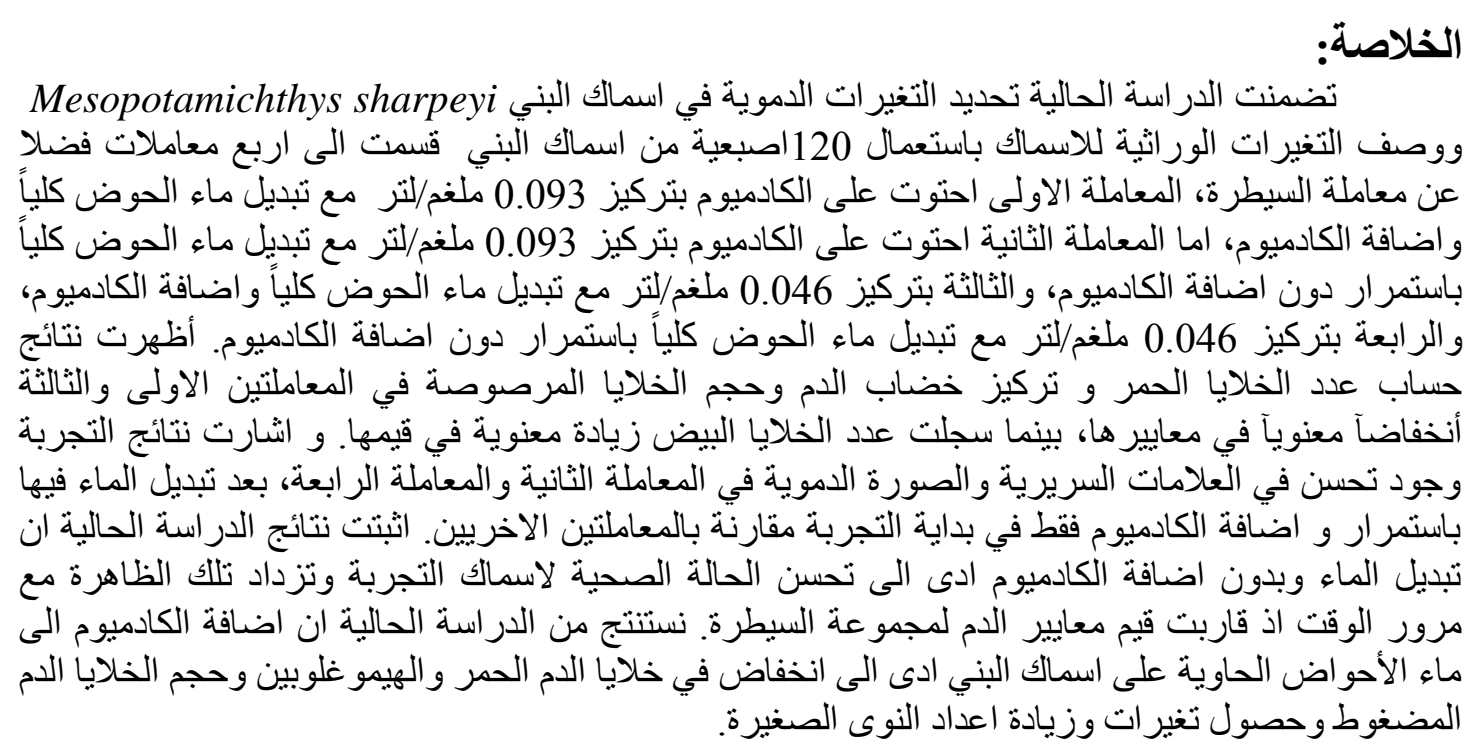

الكلمات المفتاحية:كلوريد الصوديوم، الصفات الدمية، سمكة البني. 